\title{
SURVEY OF CHICKEN ABATTOIR FOR THE PRESENCE OF Campylobacter jejuni AND Campylobacter coli
}

\section{SUMMARY}

The genus Campylobacter is of great importance to public health because it includes several species that may cause diarrhea. These species may be found in water, food and in the intestinal tract of chickens. This study investigated the presence of Campylobacter jejuni and Campylobacter coli in chicken abattoirs in São Paulo State, Brazil. A total of 288 samples of feces, feathers, scald water, evisceration water, chiller water, and the rinse water of eviscerated, not eviscerated and chilled carcasses were collected in six chicken abattoirs. Polymerase Chain Reaction (PCR) was performed in Campylobacter spp.-positive isolates using the gene HIP, specific for hippuricase enzyme from Campylobacter jejuni and aspartokinase gene, specific to detect Campylobacter coli. The percentage of positive isolates of Campylobacter jejuni was 4.9\% (14/288). Isolation was greater in feces samples $(22 \%, 8 / 36)$. One sample was positive for the species $C$. coli. In conclusion, the results indicate that it is necessary to improve quality control for Campylobacter spp. in chicken abattoirs.

KEYWORDS: Abattoir; Campylobacter coli; Campylobacter jejuni; Chicken; PCR.

\section{INTRODUCTION}

The genus Campylobacter is of great importance to public health. Several species of this genus may cause diarrhea and have been isolated with increasing frequency in humans, animals, food and water ${ }^{26}$. A great variety of species can harbor this microorganism in the intestinal tract: pigs, sheep, bovines, dogs, cats, and domestic and wild birds. During the slaughter this pathogen can be uploaded from the poultry intestine to the meat surface ${ }^{17}$.

In Brazil, Campylobacter spp. have been reported in cases of acute and chronic diarrhea, and even in individuals without disease symptoms ${ }^{21}$. In the United States, it is estimated that more than 2.5 million cases of enteritis caused by $C$. jejuni occur on a year, surpassing the number of cases of salmonellosis and shigellosis ${ }^{10}$.

The transmission of Campylobacter spp. is usually associated with the consumption of contaminated food ${ }^{22}$. Nevertheless, a great number of outbreaks have been related to water, which has been considered an important transmission route ${ }^{12}$. Campylobacteriosis outbreaks have been associated mainly to chicken meat and their subproducts ${ }^{9,19}$. The consumption of food contaminated by $C$. jejuni, especially inadequately processed or partially cooked poultry has been considered the main transmission route of enteritis in human beings ${ }^{20}$.

Two major species of the genus Campylobacter which occur in the poultry industry are Campylobacter jejuni and Campylobacter coli. Growth temperature ranges from 30 to $45{ }^{\circ} \mathrm{C}$, with optimum temperature of multiplication at $42{ }^{\circ} \mathrm{C}^{11}$. The species $C$. coli is closely related to $C$. jejuni. It is associated with poultry and swine and has been related to diseases in human beings and animals ${ }^{11}$. The species $C$. jejuni is widely present in the gastrointestinal tract of mammals and also domestic and wild birds ${ }^{17,24}$.

Campylobacter jejuni is a frequent cause of human bacterial gastroenteritis cases in industrialized and developing countries and represents a considerable drain on economic and public health resources ${ }^{1}$. The infections caused by $C$. jejuni represent the most common antecedent infection to a neuromuscular paralysis in human beings, known as Guillain-Barré syndrome?

CARVALHO et $a l .{ }^{3}$ have performed microbiological analysis of 291 samples collected in chicken abattoirs and C. jejuni has been isolated from $42 \%$ of the feces samples, $38 \%$ of the feather samples, $26 \%$ of the scald water samples, $61 \%$ of the rinse water of eviscerated carcasses, and $36 \%$ of the samples of carcasses after evisceration. The authors concluded that evisceration and plucking are critical points of contamination during slaughter and processing in chicken abattoirs.

The specific mechanism for the spread of Campylobacter spp. from animals to humans has not been elucidated yet, although it has been extensively studied. It is indispensable to establish reliable methods to

(1) Departamento de Medicina Veterinária Preventiva e Reprodução Animal, Faculdade de Ciências Agrárias e Veterinárias de Jaboticabal, Universidade Estadual Paulista, 14884-900 Jaboticabal, São Paulo, Brasil.

(2) Instituto Biológico, São Paulo, SP, Brasil.

Correspondence to: Ana L.L. Cortez, Tel./Fax: +55 16 3209-2646, E-mail: analordello@pop.com.br 
study the mechanism of Campylobacter spp. spread $^{23}$. Currently, $C$. jejuni isolates have been typed using the Polymerase Chain Reaction $(\mathrm{PCR})$ and hippuricase gene $(H I P)^{10}$.

The objectives of this study were to evaluate the presence of $C$. jejuni and $C$. coli and identify these bacteria in the processing line of chicken abattoirs.

\section{MATERIAL AND METHODS}

Sampling: A total of 288 samples of feces, feathers, scald water, evisceration water, chiller water and rinse water of eviscerated, not eviscerated and chilled carcasses were collected, by the authors, during processing in three chicken abattoirs with Federal Inspection Service SIF (B, C and F) and three chicken abattoirs with State Inspection Service - SISP (A, D and E) in São Paulo State, Brazil. After the samples were collected they were kept in refrigerated boxes and transported to the laboratory and directly processed.

Feces samples were collected at the Receiving Department and placed into sterile polyethylene bags. Feather samples were collected near the feather-plucking machine and placed into sterile polyethylene bags. The samples of scald water, evisceration water and chiller water were collected into sterilized glass flasks $(500 \mathrm{~mL})$ in a volume of 400 $\mathrm{mL}$. The samples of rinse water of eviscerated, not eviscerated and chilled carcasses were collected during processing by placing the carcasses into sterile polyethylene bags containing $300 \mathrm{~mL}$ of $0.1 \%$ peptone water. The resulting solutions were then poured into sterilized glass flasks $(500 \mathrm{~mL})$ in a volume of $400 \mathrm{~mL}$.

Isolation of Campylobacter spp. and DNA extraction: Feces samples: one g of feces was diluted with $10 \mathrm{~mL}$ of $0.9 \%$ sterile saline solution, mixed, and decanted for five minutes ${ }^{5}$. Feathers samples: 25 $\mathrm{g}$ of feathers were added to $45 \mathrm{~mL}$ of fluid thioglycollate medium (Merck). Water and carcass samples: the scald water, evisceration water, chiller water and the rinse water of eviscerated, not eviscerated and chilled carcasses were incubated for 24 hours at $42{ }^{\circ} \mathrm{C}$. Afterwards, $50 \mathrm{~mL}$ of the total volume were centrifuged at $8,000 \mathrm{~g}$ for 30 minutes at $4{ }^{\circ} \mathrm{C}^{2}$.

Two loops of each sample were inoculated in Brucella Agar (Merck) added with Campylobacter growth supplement (FBP, $0.025 \%$ ferrous sulphate, $0.025 \%$ sodium pyruvate (Merck), $0.025 \%$ sodium metabissulphite), $2 \%$ of antibiotic mixture $\left(10 \mathrm{mg} \cdot \mathrm{mL}^{-1}\right.$ vancomycin, $5 \mathrm{mg} . \mathrm{mL}^{-1}$ trimethoprim, 2.5 UI. $\mathrm{mL}^{-1}$ polymixin, $5 \mathrm{mg} . \mathrm{mL}^{-1}$ amphotericin B, $15 \mathrm{mg} \cdot \mathrm{mL}^{-1}$ cephalothin) and $7 \%$ of sheep blood, and incubated for 48 hours at $42{ }^{\circ} \mathrm{C}$ in a microaerophilic atmosphere ${ }^{2}$. Suspicious colonies of Campylobacter spp. were Gram-stained and identified according to the morphology by optical microscopy.

The DNA of positive isolates of Campylobacter spp. was extracted according to NISHIMURA et al. ${ }^{16}$. Briefly, Campylobacter spp. colonies were grown for two or three days, and three to five colonies were diluted in $1 \mathrm{~mL}$ of ultra-pure water (Milli $\mathrm{Q}^{\circledR}$ ) and boiled for 10 minutes.

Identification of Campylobacter jejuni-positive isolates: The oligonucleotides HIP400F (5'-GAA GAG GGT TTG GGT GGT G-3') and HIP1134R (5'-AGC TAG CTT CGC ATA ATA ACT TG-3') ${ }^{13}$ were used to amplify the DNA of $C$. jejuni, targeting the hippuricase gene $(H I P)$. PCR was performed with 1 x PCR buffer (Gibco- BRL), $200 \mu \mathrm{M}$ dNTPs, $2.5 \mathrm{mM} \mathrm{MgCl}$, 40 pmol of each primer, and $2.5 \mathrm{u}$ Taq DNA polymerase (Gibco- BRL), and $10 \mu \mathrm{L}$ of template DNA. The cycling was as follows: initial denaturation at $94{ }^{\circ} \mathrm{C}$ for five minutes, 30 amplification cycles of denaturation (one minute at $94{ }^{\circ} \mathrm{C}$ ), annealing (one minute at $58{ }^{\circ} \mathrm{C}$ ) and extension (one minute at $72{ }^{\circ} \mathrm{C}$ ), followed by a final extension step for 10 minutes at $72{ }^{\circ} \mathrm{C}^{13}$. Finally, the samples were loaded to $1.4 \%$ agarose gels in $0.5 \mathrm{X}$ TBE buffer (0.045M TRISBorate and $1 \mathrm{mM}$ EDTA, $\mathrm{pH}$ 8.0) to be analyzed. Positive control strains of Campylobacter jejuni used were from Canada Center for Disease Control and Prevention (CDC): CDC 913/PC-264. A negative control without template DNA was included in each PCR run. Amplified products of $C$. jejuni (gene HIP) were analyzed in $1.4 \%$ agarose gel at a constant voltage of 5-6 V.cm-1, using a 100-bp DNA ladder (GibcoBRL) as molecular size standard. The gel was photographed under UV light (300-320 nm) with a Kodak Digital Camera DC/120 Zoom. The image was analyzed using the 1D Image Analysis software (Kodak Digital Science) electrophoresis.

Identification of Campylobacter coli-positive isolates: The DNA extracted from positive isolates of Campylobacter spp. was amplified using the oligonucleotides CC18F (5'-GGT ATG ATT TCT ACA AAG CGA G-3') and CC519R (5'-ATA AAA GAC TAT CGT CGC GTG-3'), which are specific for aspartokinase gene ${ }^{13}$. PCR was performed with $1 \mathrm{x}$ PCR buffer (Gibco- BRL), $200 \mu \mathrm{M}$ dNTPs, $2.5 \mathrm{mM} \mathrm{MgCl} 2,40$ pmol of each primer, and $2.5 \mathrm{u}$ Taq DNA polymerase (Gibco- BRL), and $10 \mu \mathrm{L}$ of template DNA. The cycling was as follows: denaturation for five minutes at $94{ }^{\circ} \mathrm{C}, 30$ amplification cycles of denaturation (one minute at $94{ }^{\circ} \mathrm{C}$ ), annealing (one minute at $60{ }^{\circ} \mathrm{C}$ ) and extension (one minute at $72{ }^{\circ} \mathrm{C}$ ). Samples were submitted to an extension step for 10 minutes at $72{ }^{\circ} \mathrm{C}^{13}$. Positive control strains of Campylobacter coli used were from USA CDC: ATCC A3315. A negative control without template DNA was included in each PCR run. Finally, samples were analyzed and photographed as described previously.

Statistical analyses were performed using the software SAS 8.0 System (SAS Institute, 2002).

\section{RESULTS}

The Table 1 exhibits the percentage of Campylobacter jejunipositive isolates in each collection points. The highest isolation percentages of $C$. jejuni were found in feces samples $(22.2 \%, 8 / 36)$, following by feathers and rinse water of eviscerated carcasses $(5.6 \%$, 2/36). Positive isolates (Fig. 1) for C. jejuni were in number of 14 $(4.9 \%)$ and distributed as follows: five in abattoir $\mathrm{D}$, four isolates in abattoir $\mathrm{E}$, three isolates in abattoir $\mathrm{B}$, one isolate in abattoir $\mathrm{C}$ and $\mathrm{F}$. No positive sample was found in abattoir A. From the 288 evaluated in the specific PCR 14 samples were positive for $C$. jejuni. One feather sample was positive for $C$. coli in the abattoir E, which has SISP inspection.

\section{DISCUSSION}

From a total of 288 samples, $4.9 \%(14 / 288)$ were positive for the species $C$. jejuni. SCARCELLI et al. ${ }^{20}$ analyzed 55 chicken samples 


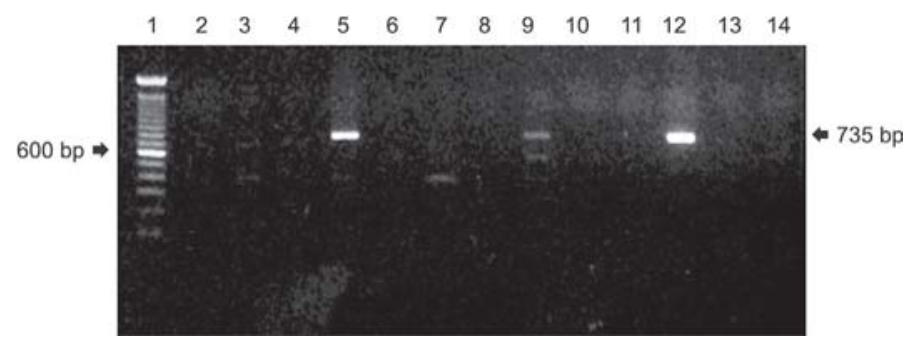

Fig. 1 - Electrophorese gel of Campylobacter jejuni samples, targeting the hippuricase gene $(H I P)$, from chicken abattoirs. C. jejuni-positive samples (lanes 5, 9); C. jejuni-negative samples (lanes 2, 3, 4, 6, 7, 8, 10, 11, 14); positive control, CDC 913/PC-264 (lane 12); negative control without DNA (lane 13); 100 bp DNA Ladder (lane 1).

\section{Table 1}

Positive isolates for Campylobacter jejuni collected in the processing lines of chicken abattoirs from March 2003 to August 2004, São Paulo State, Brazil

\begin{tabular}{|c|c|c|c|}
\hline Samples & $\begin{array}{l}\text { Number } \\
\text { of samples }\end{array}$ & $\begin{array}{l}\text { C. jejuni-positive } \\
n\end{array}$ & $\begin{array}{l}\text { samples } \\
\%\end{array}$ \\
\hline Feces & 36 & 8 & 22.2 \\
\hline Feathers & 36 & 2 & 5.6 \\
\hline Scald water & 36 & 1 & 2.8 \\
\hline Evisceration water & 36 & 1 & 2.8 \\
\hline Chiller water & 36 & 0 & 0.0 \\
\hline $\begin{array}{l}\text { Rinse water of not } \\
\text { eviscerated carcasses }\end{array}$ & 36 & 0 & 0.0 \\
\hline $\begin{array}{l}\text { Rinse water of } \\
\text { eviscerated carcasses }\end{array}$ & 36 & 2 & 5.6 \\
\hline $\begin{array}{l}\text { Rinse water of } \\
\text { chiller carcasses }\end{array}$ & 36 & 0 & 0.0 \\
\hline Total & 288 & 14 & 4.9 \\
\hline
\end{tabular}

and reported $20 \%$ C. jejuni-positive isolates, CASON et al. ${ }^{4}$, in United States, have reported an occurrence of $20 \%$ of Campylobacter spp. in chicken carcasses. Both researches show values higher than the present findings.

In the present study $C$. coli was detected only in $0.35 \%$ of the samples. These results are lower than the values reported by ERTAS et $a l^{8}{ }^{8}$, who analyzed liver and intestine samples of 200 chickens and reported $11 \%$ of positivity for $C$. coli. NIELSEN \& NIELSEN ${ }^{15}$ stated that the occurrence of positive samples for C. coli was $15 \%$ out of 156 samples in different poultry products. These results demonstrate high variation in the occurrence of $C$. coli. Studies on the prevalence of campylobacteriosis in poultry have indicated that $C$. jejuni is more commonly found than C. coli $^{8,11}$.

ZHAO et al. ${ }^{26}$ analyzed 184 samples of raw chicken meat in the United States, from which the majority $(70.7 \%)$ was positive for Campylobacter spp. In Brazil, high percentages of $C$. jejuni and $C$. coli (from $25 \%$ to $50 \%$ ) have been isolated from feces of healthy chickens ${ }^{5,14}$. It has been reported that the prevalence of $C$. jejuni in poultry products might vary from 0 to $100 \%{ }^{11}$. The presence of $C$. jejuni and $C$. coli in poultry carcasses might be fundamental to transmission to human beings ${ }^{8}$.
In this work, despite the high frequency of Campylobacter spp. in feces samples $(22.2 \%)$, only one sample $(2.8 \%)$ of the evisceration water presented contamination with $C$. jejuni, and the presence of Campylobacter spp. in chiller water samples and rinse water of chilled carcasses was not observed. Differently from the present findings, CASTRO et al. ${ }^{5}$ have detected higher percentages of $C$. jejuni contamination in the evisceration water $(35.7 \%)$ and have also detected Campylobacter spp. in scald and chiller water samples. The scalding at $58{ }^{\circ} \mathrm{C}$ decreased Campylobacter spp. contamination in the carcasses, but did not eliminate it completely ${ }^{18}$.

In abattoir A, there were no positive samples for $C$. jejuni probably because there was no contamination of the flocks that were processed in the sampling days. The chicken flocks evaluated in the present study originated from different places and there was no isolation of Campylobacter spp. from the samples of some flocks. Therefore, it is possible that such flocks were not infected by Campylobacter spp., probably because antibiotics had been added to the diet in the farms.

Reproducible and discriminatory methods are necessary to identify the origin of infections and to outline the transmission routes ${ }^{6}$. Besides, new laboratory techniques are necessary to differentiate between nonepidemiologically related outbreaks ${ }^{10}$. Frequent food contamination by multiple strains of Campylobacter spp. has been hindering the delimitation of transmission routes and the recognition of outbreaks ${ }^{6}$.

Data corroborate the hypothesis that chickens might play an important role as a transmission route of Campylobacter spp. to human beings. These results emphasize the importance of improving control measures and both hygiene and sanitary conditions in chicken abattoirs.

The statistical analysis (Fisher test, $\alpha=0.05)^{25}$ indicated that there were no significant differences between the presence and absence of Campylobacter spp. in the six abattoirs $(\mathrm{p}>0.05)$. There were also no significant differences between the presence and absence of Campylobacter spp. in the different abattoirs evaluated (SIF or SISP) $(p>0.05)$. On the other hand, there were significant differences between the presence and absence of Campylobacter spp. in the eight sampling points evaluated $(\mathrm{p} \leq 0.05)$.

\section{RESUMO}

\section{Pesquisa de Campylobacter jejuni e Campylobacter coli em abatedouros de aves}

O gênero Campylobacter tem grande destaque em saúde pública, principalmente por pertencerem a este gênero várias espécies que podem causar diarréia. Estas espécies podem ser encontradas em amostras de água, alimentos e no trato intestinal das aves. Este estudo investigou a presença de Campylobacter jejuni e Campylobacter coli em abatedouros de aves no Estado de São Paulo. As 288 amostras foram coletadas em seis estabelecimentos e incluíram: fezes; penas; água de escaldamento, de evisceração e de resfriamento; e água de enxaguadura de carcaça não eviscerada, eviscerada e resfriada. Após o isolamento microbiológico das amostras positivas de Campylobacter spp. foi realizada uma Reação em Cadeia da Polimerase (PCR) utilizando o gene $H I P$, da hipuricase, específico para Campylobacter jejuni e o gene da enzima aspartoquinase, específico para 
CORTEZ, A.L.L.; CARVALHO, A.C.F.B.; SCARCELLI, E.; MIYASHIRO, S.; VIDAL-MARTINS, A.M.C. \& BÜRGER, K.P. - Survey of chicken abattoir for the presence of Campylobacter jejuni and Campylobacter coli. Rev. Inst. Med. trop. S. Paulo, 48(6): 307-310, 2006.

Campylobacter coli. A porcentagem de amostras positivas para Campylobacter spp. foi de 4,9\% (14/288), sendo que o isolamento foi maior em amostras de fezes $(22 \%, 8 / 36)$. Foi isolada uma amostra positiva para C. coli. Em conclusão, os resultados indicam que há uma necessidade de melhorar a qualidade higiênico-sanitária do controle de Campylobacter em abatedouros de aves.

\section{ACKNOWLEDGEMENTS}

The authors gratefully thank Fabio Kiyohara for critically reading the manuscript. This research work was financially supported by Brazilian National Council for Scientific and Technological Development $(\mathrm{CNPq})$ and by the State of São Paulo Research Support Foundation (FAPESP).

\section{REFERENCES}

1. BUTZLER, J.P. - Campylobacter, from obscurity to celebrity. Clin. Microbiol. Infect., 10: $868-876,2004$

2. CARVAlHO, A.C.F.B. \& CORTEZ, A.L.C. - Contaminação de produtos avícolas industrializados e seus derivados por Campylobacter jejuni e Salmonella sp. Ars Vet., 19: 57-62, 2004

3. CARVALHO, A.C.F.B.; LIMA, V.H.C. \& PEREIRA, G.T. - Determinação dos principais pontos de risco de contaminação de frangos por Campylobacter, durante o abate industrial. Hig. Aliment., 16: 89-94, 2002.

4. CASON, J.A.; BAILEY, J.S.; STERN, N.J.; WHITTEMORE, A.D. \& COX, N.A. Relationship between aerobic bacteria, Salmonellae, and Campylobacter on broiler carcasses. Poult. Sci., 76: 1037-1041, 1997.

5. CASTRO, A.G.M.; GENOVEZ, M.E.; SCARCELLI, E. et al. - Monitoramento de Campylobacter spp. ao longo da linha de abate de frangos de corte. Arq. Inst. Biol., 64: 21-26, 1997.

6. DESAI, M.; LOGAN, J.M.J.; FROST, J.A. \& STANLEY, J. - Genome sequence-based fluorescent amplified fragment length polymorphism of Campylobacter jejuni, its relationship to serotyping, and its implications for epidemiological analysis. J. clin. Microbiol., 39: 3823-3829, 2001.

7. DUIM, B.; WIN, A.C.; VAN BELLKUM, A. et al. - Amplified fragment length polymorphism analysis of Campylobacter jejuni strains isolated from chickens and patients with gastroenteritis or Guillain-Barré or Miller Fisher syndrome. Appl. environ. Microbiol., 66: 3917-3923, 2000.

8. ERTAS, H.B.; ÇETINKAYA, B.; MUZ, A. \& ÖNGOR, H. - Genotyping of broileroriginated Campylobacter jejuni and Campylobacter coli isolates using fla typing and random amplified polymorphic DNA method. Int. J. Food Microbiol., 94: 203 209, 2004

9. EVANS, S.J. - Introduction and spread of thermophilic Campylobacter in broilers flocks. Vet. Res., 131: 574-576, 1992.

10. FITZGERALD, C.; HELSEL, L.O.; NICHOLSON, M.A. et al. - Evaluation of methods for subtyping $C$. jejuni during an outbreak involving a food handler. J. clin. Microbiol., 39: 2386-2390, 2001.
11. GENIGEORGIS, C. - A importância do Campylobacter na avicultura. Avicult. Industr., 6: 6-12, 1987.

12. JONES, I.G. \& ROWORTH, M. - An outbreak of Escherichia coli O:157 and campylobacteriosis associated with contamination of a drinking water supply. Publ. Hlth (Lond.), 110: 277-282, 1996.

13. LINTON, D.; LAWSON, A.J.; OWEN, R.J. \& STANLEY, J. - PCR detection, identification to species level and fingerprint of Campylobacter jejuni and Campylobacter coli direct from diarrheic samples. J. clin. Microbiol., 35: 2568-2572, 1997.

14. MACHADO, R.A.; TOSIN, I. \& LEITÃO, M.F.F. - Occurrence of Salmonella sp. and Campylobacter sp. in chickens during industrial processing. Rev. Microbiol. (S. Paulo), 25: 239-244, 1994.

15. NIELSEN, E.M. \& NIELSEN, N.L. - Serotypes of $C$. jejuni and C. coli isolated from poultry products. Int. J. Food Microbiol., 46: 199-205, 1999.

16. NISHIMURA, M.; NUKINA, M.; YUAN, J.M. et al. - PCR-based restriction fragment length polymorphism (RFLP) analysis and serotyping of Campylobacter jejuni isolated from diarrheic patients in China and Japan. FEMS Microbiol. Lett., 142: 133-138, 1996.

17. OOSTEROM, J. - Campylobacter jejuni in foods of animal origin. In: Report on a WHO consultation on epidemiology and control of campylobacteriosis in animals and humans. Bilthoven, WHO Publishing, 1994. p. 184.

18. OOSTEROM, J. \& DE WILDE, G.J.A. - Origin and prevalence Campylobacter jejuni in poultry processing. J. Food Protect., 46: 339-344, 1983

19. PEARSON, A.D.; GREENWOOD, M.H.; DONALDSON, J. et al. - Continuous source outbreak of campylobacteriosis traced to chicken. J. Food Protect., 63: 309-314, 2000 .

20. SCARCELLI, E.; MIYASHIRO, S.; PIATTI, R.M. et al. - Emprego da técnica do polimorfismo de comprimentos dos fragmentos de restrição (RFLP) do produto obtido pela reação de polimerase em cadeia (PCR) do gene FLA A na subtipagem de amostras de Campylobacter jejuni subspp. jejuni isoladas de frangos de corte e humanos. Arq. Inst. Biol., 70 (supl. 3): 1-5, 2003.

21. SCARCELLI, E.; GENOVEZ, M.E.; CARDOSO, M.V. et al. - Avaliação do potencial de disseminação de Campylobacter spp. por diferentes espécies animais. Arq. Inst. Biol., 65: 55-61, 1998.

22. SKIRROW, M.B. \& BLASER, M.J. - Campylobacter jejuni. In: BLASER, M.J. et al. Infections of the gastrointestinal tract. New York, Raven Press, 1995. p. 184.

23. STEINHAUSEROVA, I.; CESKOVA, J. \& NEBOLA, M. - PCR/restriction fragment length polymorphism (RFLP) typing of human and poultry Campylobacter jejuni strains. Lett. appl. Microbiol., 34: 354-358, 2002.

24. TOOD, E.C.D. - Foodborne disease in Canada- a 10-years summary from 1975-1984. J. Food Protect., 55: 123-132, 1992.

25. ZAR, J.H. - Biostatistical analysis. New Jersey, Prentice Hall, 1999.

26. ZHAO, C.; GE, B.; VILLENA, J. et al. - Prevalence of Campylobacter spp., Escherichia coli, and Salmonella serovars in retail chicken, turkey, pork, and beef from the Greater Washington, D.C., area. Appl. environ. Microbiol., 67: 5431-5436, 2001

Received: 19 October 2005

Accepted: 29 June 2006 